\title{
The Status of Transgender Men Heir in Patrilineal System of Adat Inheritance Law
}

\author{
Katherine Abidea Salim \\ katherineabidea@gmail.com \\ Universitas Airlangga
}

Keywords:
Adat Inheritance
Law; Inheritance
rights; Patrilineal
System;
Transgender men.

\begin{abstract}
Technology has enabled individuals with gender dysphoria - that is, those with a sense of incompatibility between gender and biological sex, to undergo sex reassignment surgery. Indonesia is one country which recognizes the right to legal recognition of sex reassignment. Nonetheless, the issue of sex change remains a taboo one in Indonesia, where religion and adat play important roles. Many Adat systems in Indonesia adopt a patrilineal inheritance system, where only sons may inherit, but have no established rules as to the ability of transgender men, born as women, to inherit. This article seeks to answer the question of whether transgender men have the right to a share of any, if at all, of their fathers' inheritance. The author uses normative legal research using various sources of law, especially those found in statutes and regulations doctrines, and jurisprudences. In addition, secondary sources on Adat and inheritance law are used as supplementary sources. The research concludes that the change of biological sex does enable transgender men, who were prior to sex reassignment surgery not entitled to any inheritance, to inherit their fathers' inheritance. This is owed to the fact that the ability to inherit in Indonesian Adat systems is concerned solely with the ability to carry family name, and not the ability to procreate as a man.
\end{abstract}

\section{Kata Kunci:}

Hukum Waris

Adat; Hak

Mewaris; Sistem

Patrilineal;

Transgender pria.

\begin{abstract}
Abstrak
Perkembangan teknologitelahmembuat individu yang mengalami disforia gender, yaitu mereka yang merasa jenis kelamin biologis dan identitas gender mereka berbeda, untuk melakukan operasi ganti kelamin. Penggantian jenis kelamin ini merupakan suatu hal yang tabu di Indonesia, dimana peran agama dan adat sangat berpengaruh. Banyak dari hukum adat yang menganut sistem patrilineal dalam hukum pewarisannya, dimana hanya anak laki-laki yang boleh mewaris, namun tidak memiliki peraturan mengenai transgender pria atau transpria. Artikel ini mencoba untuk mencari solusi untuk pertanyaan apakah transpria mempunyai bagian dalam harta warisan dari ayahnya. Metode yang digunakan di dalam penelitian ini adalah metode penelitian hukum normatif dimana penulis mengkaji berbagai peraturan perundang-undangan, keputusan pengadilan, serta pendapat para sarjana. Sebagai tambahan, sumber hukum sekunder digunakan untuk melengkapi sumber utama. Berdasarkan hasil penelitian, perubahan jenis kelamin seseorang berpengaruh terhadap hak mewaris; yakni, seorang transpria yang sebelumnya tidak mewaris karena lahir sebagai perempuan, kemudian dapat melanjutkan garis keturunan keluarga secara hukum sehingga dapat mewaris. Hal ini dikarenakan bahwa di dalam hukum waris adat, hal utama yang diperhatikan adalah kemampuan untuk melanjutkan nama keluarga dan bukan kemampuan untuk melahirkan anak biologis.
\end{abstract}


Katherine Abidea: The Status of Transgender...

\section{Introduction}

Sex and gender has been equated for the longest of time as people perceive gender and sex conventionally, where females are associated with feminism and males are associated with masculinity. However, these two terminologies are in fact used to denote different concepts. The difference between the two is best captured by the writing of early feminist writer, namely Simone de Beauvoir, in her book saying: "one is not born a woman, but rather becomes one". In doing so, she drew a distinction between having a female genital, typically associated with womanhood, with the gender identity of being a woman. ${ }^{1}$ Sex is biological matter that refers to the differences in the organs, hormones, and chromosomes between males and females, whereas gender pertains to the roles and expectations attributed to males and females in society.

Judith Butler's seminal book, Gender Trouble, introduced the idea of gender as "performativity", that it is something a human being continually does, as opposed to what they 'are'; she argued for the cultural and social nature of gender as an element that are fluid and not biologically based. ${ }^{2}$ The book has been accepted in modern feminist theory as the basis of queer theory that gives 'gender' a meaning that goes beyond what socially and culturally constructed. Her work is the main reference for the development of queer studies, and had profound influence on people's understandings of gender. ${ }^{3}$

The discrepancy between sex and gender could affect the mental health of a person which is known by the name of Gender Dysphoria. The diagnosis of Gender Dysphoria applies to those who exhibit clinically significant distress caused by the incongruence between their expressed gender and their assigned sex. ${ }^{4}$ The people diagnosed with Gender Dysphoria usually seek hormone

\footnotetext{
1 Simone de Beauvoir, The Second Sex (Vintage 2010).[125].

2 Judith Butler, Gender Trouble: Feminism and the Subversion of Identity (Routledge 1990).[148].

3 Warren J. Blumenfeld, Margaret Soenser Breen, 'Introduction to the Special Issue: Butler Matters: Judith Butler's Impact on Feminist and Queer Studies Since Gender Trouble' (2001) 6 International Journal of Sexuality and Gender Studies.[13].

4 et al William Byne, 'Gender Dysphoria in Adults: An Overview and Primer for Psychiatrists' (2018) 3 Transgender Health.[60].
} 
treatment and also sex reassignment surgery to transition their sex in accordance with their expressed gender.

The first known sex reassignment surgery (SRS) case in the world is done by Einar Wegener from Denmark in 1930 whon changed her sex from male to female and goes by the name Lili Elbe. ${ }^{5}$ Lili first discovered her gender identity as a woman after her wife asked Lili to be the wife's model and then began to change her way of life. Afterwards, Lili decided to undergo four surgical procedures to transform her body from male to female known as SRS in the present day. Through these surgeries, Lili was able to change her name and sex legally, even to receive a passport with her new name and sex identity. However, the procedure was very dangerous at that time and she later died from postoperative complications.

In the present time, the danger of SRS that aims for the change in physical organs has consistently decreased alongside the development of technology. SRS itself is a procedure to surgically remove body parts from a person in order to make their sexual characteristics resemble those of the opposite sex. ${ }^{6}$ This type of surgery is now seen as a viable option for those with gender dysphoria who wished to change their sex in accordance with their gender.

In Indonesia, the first SRS was done by a man born with the name of Khan Kok Hian or Iwan Robbyanto Iskandar. Iwan changed his physical sex in Singapore in the year of 1973 and later came back to Indonesia as a woman named Vivian Rubiyanti Iskandar. She is the first person to ever request to legally change her sex identity, after surgically changing her sex, to the Jakarta District Court. Eventually, the Court accepted her request with Judgment on November 11th, $1973 .^{7}$

\footnotetext{
5 Naomi Blumberg, 'Lili Elbe: Danish Painter' (Encyclopedia Britannica, 2015).

6 et al Dhejne C. Lichtenstein, 'Long-Term Follow-Up of Transsexual Persons Undergoing Sex Reassignment Surgery: Cohort Study in Sweden' (2011) 6 PLoS One.[1].

7 Hendri F. Isnaeni, 'Viva Vivian' (Historia, 2019) < https://historia.id/kultur/articles/viva-vivian-6a8JP> accessed 6 April 2020.
} 
Another example of female-to-male sex change is the case of Angelina Karunianta Kaban. Angelina was born and registered as a woman in Indonesia, and later developed a Harry Benjamin Syndrome. She went through Hormone Replacement Therapy in 2013 and also mastectomy surgery in 2015. She asked Surabaya District Court to change her sex before the law as according to Article 56 Law number 23 of 2006 concerning Citizenship Administration, no one can change their identity in any legal documents unless there is a judgment from the Court. To support her argument, she also cites judgments such as: Supreme Court judgments on Vivian Rubiyanti and Dorce Gamalama. In 2018, her request was granted with Judgment No. Number 583/Pdt.P/2016/PN Sby.

The number of people taking SRS has increased rapidly over time. ${ }^{8}$ Since 1973, there exist at least 13 more cases about persons changing their sex openly in Indonesia. This increasing number of SRS, while triggering social issues in their wake, also triggers legal questions on the application of inheritance law in Indonesia. This legal issue occurs, as prime example, at the adat inheritance law that is infamously known with its strict, conventional regulation as few of the systems in this branch depends heavily on the difference between sex as the determination of rights between male and female descent.

According to Ter Haar, adat inheritance law is a set of rules that regulates how inheritance, whether concrete or not, can be inherited and succeeded from generation to generation. ${ }^{9}$ Soerojo Wignjodipoero had a similar view and clarified the meaning of adat inheritance law. In his opinion, adat inheritance law includes legal norms that establish which inheritance can be inherited to the heirs. At the same time, it also regulates the method and process of the inheritance succession. ${ }^{10}$ Adat inheritance law is recognized by the state law of Indonesia as it has been stated within Article 18B paragraph (2) of the Indonesian Constitution and has existed concurrently with the state law.

8 Canner JK et. al, Harfouch O, Kodadek LM, 'Temporal Trends in Gender-Affirming Surgery Among Transgender Patients in the United States' (2018) 153(7)' (2018) 153 JAMA Surgery.[615].

9 Ter Haar, Asas-Asas Dan Susunan Hukum Adat (Balai Pustaka 1990).[47].

10 Soerojo Wignjodipoero, Pengantar Dan Asas-Asas Hukum Adat (PT Temprin 1990).[161]. 
In adat inheritance law, there exist four different systems of kinship: ${ }^{11}$

1. Patrilineal system. This system gives priority to the male descent rather than the female descent, causing the male heirs to have a higher status and inheritance rights in the family;

2. Matrilineal system. This system gives priority to the female descent rather than the male descent, making the female heirs to have the higher status and inheritance right;

3. Bilineal system or double descent. This system divides the rights for each descent, where for some rights, it was succeeded only to male descent and for some other rights, it was succeeded only to female descent;

4. Bilateral system. This system believes that the rank and status from both the male and the female are equal and thus they embrace the same inheritance rights.

The inheritance rights owned by females and males are different in some systems of the adat inheritance law. Therefore it generates a question on what the norms are in the adat system that will regulate the inheritance in the event of change of biological sex. This article will solve this question by answering two major points: (1) what are the general norms in the patrilineal adat system and its reasoning fundamentally and; (2) how the change of biological sex affects the application of such norms.

Aside from adat inheritance law, Indonesia also adheres to two other systems, namely the Islamic inheritance law and Burgerlijk Wetboek inheritance law. According to the Indische Staatsregeling (IS), the Islamic inheritance law is applicable for the Muslims, the Burgerlijk Wetboek inheritance law is applicable for the European, and the adat inheritance law is applicable for bumiputera and foreign easterners. ${ }^{12}$ These three different sets of rules exist concurrently as Indonesia adheres to the pluralism of inheritance law and is yet to develop any new law to replace the three.

\footnotetext{
${ }^{11}$ Sri Hajati, et.al, Buku Ajar Hukum Adat (Airlangga University Press 2018).[245].
}

12 Article 131 of Indische Staatsregeling; Article 163 of Indische Staatsregeling. 
Katherine Abidea: The Status of Transgender...

The method used in this article is the normative legal research with the primary sources of law being statutes and regulations, doctrines, and also jurisprudences concerning adat inheritance law. Additionally, as the secondary sources of law, the author uses adat law and custom to supplement. The purpose of this method is to discover the norms believed by the adat community that later becomes the basis for the people to solve disputes concerning the effect of SRS to inheritance law. With this methodology, the author aims to answer a hypothetical question of inheritance rights for transgender men in the patrilineal system of adat inheritance law.

\section{Patrilineal System of Adat Inheritance Law}

In the system of Adat inheritance law, the community lives by the norm that is passed by their descendants through generations. As stated supra, the patrilineal system of adat law prioritizes the male descent rather than the female descent. In adat community that adopts to the patrilineal system, the male descent of the family are prepared to be the successor of the family, and the female descent are prepared to join other families to succeed the husband's family.

Adat inheritance law has specific principles, which differentiate itself amongst other systems, that are: ${ }^{13}$

1. There exists no legitieme portie, as the people considers the interest of the heir to distribute the inheritance;

2. The distribution of inheritance must be in harmony, where each heir understand the interests of one another;

3. Inheritance can be distributed even before the inheritor passed away;

4. Equality in distribution portion of the inheritance.

${ }^{13}$ Sri Hajati et. al, Buku Ajar Hukum Waris (Adat, Islam Dan Burgerlijk Wetboek) (Airlangga University Press 2018).[7]. 
In the patrilineal system of adat inheritance law, the marriage of a female descendant is seen as her statement of "exiting her biological family to her husband's" together with her future child. Prior to the matrimony, the husband will pay a sum of money called jujur to the female's family as an exchange of payment for the transaction of "buying" her to his family. Following the acceptance of the payment, the female will automatically be released off of her biological family's name. This type of marriage is called perkawinan jujur.

In this system, "the heirs" only refers to the biological and adopted sons, the parent of the inheritor, and biological brothers of the inheritor. ${ }^{14}$ The widow will originally be barred from any inheritance, yet, jurisprudence has amended this culture. For example, the Supreme Court Judgment Number 387 K/Sip/1958 which stated that a widower is entitled to half of the inheritance of the spouse's when they were married. Another example is the Supreme Court Judgment Number 70 K/Sip/1963 which stated that in the event where the inheritor has no descendant, all of the inheritance will automatically be assigned to the widow.

\section{Transgender Man's inheritance rights in Patrilineal Adat Communities}

This part of the research aims to find the background behind the custom of patrilineancy. The first example is seen in the custom of the Nias adat community. Nias adat community adheres to the patrilineal system, where the status of 'father' (male) is the highest in the family lineage. In Nias families, the line of descent is traced through the family name (Mado in Nias language). After the marriage of the female descent, she will automatically be released off of her father's lineage and her father's family name is no longer used to identify her. This custom can be seen as a married woman is called with a nickname. ${ }^{15}$ As the female descent no longer bare the family lineage, Nias adat community permits only the male descent as the sole heir of his family's inheritance as the successor of the family lineage.

\footnotetext{
14 Eman Suparman, Intisari Hukum Waris Indonesia (Mandar Maju 1995). [56].

${ }^{15}$ Memori Perdamaian Laoli, 'Pelaksanaan Pembagian Warisan Pada Masyarakat Adat Nias (Studi Pada Masyarakat Adat Nias Di Kabupaten Nias Selatan)' (2017) 1 Premise Law Journal.[9].
} 
Katherine Abidea: The Status of Transgender...

Additionally, the male descent in Nias adat community also lives in his parent's house after his marriage, while the female descent no longer lives with her parents after marriage. This practice shows that the female descent will leave the family whereas the male descent will continue the family.

The second example is the custom of the Batak adat community. Batak is one of the adat communities in Indonesia that still adheres to the patrilineal norms. The people in the community distribute their inheritance before and after the inheritor passed away. This mechanism is used to prevent dispute between the entitled heirs. Despite adopting the patrilineal kinship, Batak adat community will not completely bar the female descendants to claim for her inheritance. Both descents have inheritance rights, however the portion of inheritance for the male counterpart will be marginally bigger in comparison with the female counterpart. According to the people of Batak adat community, the disparity is as such due to two reasons: First, the female descent will obtain inheritance from her husband, and second, the belief that it is not appropriate for a female to have more than half of the male descent portion. ${ }^{16}$ Another supporting reason can also be traced back to the practice of the community as the male descent has the obligation to provide and support his female siblings financially or to give her land. ${ }^{17}$

The third example is the Bali adat community. Bali adat community adheres to the system of kepurusa which entails the practice of perkawinan jujur. Hence, due to this practice, Bali adat community believes that the male descent has more stability in his status as the successor of the family lineage in comparison with the female as they are subject to possible deletion from their biological lineage after marriage. Therefore, the portion of inheritance for the female descent from her biological family will, automatically, not be taken into account as she is no longer part of her former family. ${ }^{18}$ On the other hand, the males will have inheritance

${ }_{16}$ Maskun Nasution \& D., Amsia, T., 'Sistem Pewarisan Pada Masyarakat Batak Toba Di Kecamatan Natar Kabupaten Lampung Selatan' (2015) 3 Jurnal Pendidikan dan Penelitian Sejarah.[7].

17 Yayasan Lembaga Bantuan Hukum Indonesia (YLBHI) dan AusAI, Panduan Bantuan Hukum di Indonesia (Sentralisme Production 2006).[103-104].

18 Ni Kadek Setyawati, 'Kedudukan Perempuan Hindu Menurut Hukum Waris Adat Bali Dalam Perspektif Kesetaraan Gender’ (2017) 1 Jurnal Penelitian Agama Hindu.[620]. 
rights due to the tradition that the male is the owner of the family heritage and is the financial provider for his family. ${ }^{19}$

The three practice examples above contain the general fundamental norms of patrilineal system in adat inheritance law that have existed since and will always be preserved for generations. The patrilineal system highlights the disparity of inheritance rights between a female and her male counterparts. In Nias adat community, only the male descent has inheritance rights as the female descent will leave the father's lineage to join the husband's family lineage. In Batak adat community, the male descent has a bigger portion of inheritance rights as the male descent has more burden to support for the female siblings and for his future family, and he also continues the family lineage. Lastly, in Bali adat community, the male descent has inheritance rights because the female descent is considered as a part of the husband family and does not continue the family lineage.

According to the pattern traced at the three examples of the patrilineal system in adat community supra, the male descent is the one who will continue his family lineage and is burdened with the obligation to financially provide his family. Therefore, the portion of the inheritance will follows the idea of "masculinity" that is dependent on the rights and obligations the adat community imposes on the individual in question. Transgender men, based on the set of judgments mentioned supra, will oftentimes file a request to the Court to change their sex identity legally. After the Court granted it, the transgender man will assume his role in his society in accordance with his "new" sexual appearance. Hence, transgender men will become the bread-winner for his family and is given the same rights and obligations as his other male counterparts. Therefore, referring to the idea that the portion of inheritance follows the rights and obligation of the individual in question, transgender men considered as male in adat community who owe equal portion of the claim to his family inheritance rights like his other biologically male counterparts.

${ }^{19}$ Ni Nyoman Sukerti et. al, 'Pewarisan Pada Masyarakat Adat Bali Terkait Ahli Waris Yang Beralih Agama’ (2016) 2 Acta Comitas.[135]. 
Until the present time, Nias adat community's view about the inheritance system has not changed, however, in Batak adat community this strict patrilineal view slowly shifts due to the increasing awareness of human rights law. Through the Supreme Court Judgement Number 179 K/Sip/1961, the Court has stated that 'in the light of humanity and general justice and the essence of equality between man and woman, a woman must be considered as an heir and has the right to inherit her parent's inheritance. A Supreme Court Judgment No. 4766 K/Pdt/1998 also appeals to the norms of the Bali adat community. The judgment states that women in Bali have the inheritance rights even when the inheritance system in Bali is patrilineal system. To this date, few Supreme Court judgments have upheld the same belief that a woman, though in a patrilineal system, will also be entitled to inheritance rights, since 1961 and thus this norm has become jurisprudence. This jurisprudence shows that the norms in the adat community have shifted as the people of the community have started to get aware of equality between male and female. Consistent with the jurisprudence, the status of transgender becomes even more irrelevant as both man and woman have rights to enjoy the family's inheritance.

\section{Conclusion}

In the patrilineal system of adat inheritance law, inheritance rights are reserved as priority to the male descent based on two reasons which reflects the fundamental norms and belief of the adat community: (1) male descent has steadier line of lineage due to the perkawinan jujur mechanism that demands the deletion of female descent from her biological lineage after marriage; (2) male descent has the obligation to financially provide the female descent of the family. However, these two norms are not dependent on the individual's physical sex at birth and the individual's ability to procreate. Rather, it depends on the roles that person assumes in their society as the final determinant of their rights to their family's inheritance.

Transgender men, who have changed his sex through surgeries, will automatically presume the roles as the 'man of the family', as his gender and sex is now both are male. As he now also assumes the role to continue the family lineage 
and financially provide for the female descent of the family, he should too, has the inheritance rights despite not being born as a man. With the recent development of the law, as seen on the consistent precedents of woman upheld the same inheritance rights with man, transgender status of someone has even further relevance with his rights as an heir. The norm found in jurisprudence recognized inheritance rights owned not only by the family lineage successor. As both female and male descent enjoy inheritance rights, transgender men should also be given equal right to his inheritance portion prevailing over the judgment of his sex and gender.

\section{Bibliography}

\section{Books}

AusAI YLBHI (YLBHI) dan, Panduan Bantuan Hukum Di Indonesia (Sentralisme Production 2006).

Blumberg N, ‘Lili Elbe: Danish Painter' (Encyclopedia Britannica 2015).

Eman Suparman, Intisari Hukum Waris Indonesia (Mandar Maju 1995).

Judith Butler, Gender Trouble: Feminism and the Subversion of Identity (Routledge 1990).

Simone de Beauvoir, The Second Sex (Vintage 2010).

Soerojo Wignjodipoero, Pengantar Dan Asas-Asas Hukum Adat (PT Temprin 1990).

Sri Hajati, et.al, Buku Ajar Hukum Adat (Airlangga University Press 2018).

Sri Hajati et. a., Buku Ajar Hukum Waris (Adat, Islam Dan Burgerlijk Wetboek) (Airlangga University Press 2018).

Ter Haar, Asas-Asas Dan Susunan Hukum Adat (Balai Pustaka 1990).

\section{Journals}

Canner JK, Harfouch O, Kodadek LM et. al., 'Temporal Trends in GenderAffirming Surgery Among Transgender Patients in the United States' (2018) 153(7)' (2018) 153 JAMA Surgery.

Dhejne C. Lichtenstein et. al., 'Long-Term Follow-Up of Transsexual Persons 
Undergoing Sex Reassignment Surgery: Cohort Study in Sweden' (2011) 6 PLoS One.

Memori Perdamaian Laoli, 'Pelaksanaan Pembagian Warisan Pada Masyarakat Adat Nias (Studi Pada Masyarakat Adat Nias Di Kabupaten Nias Selatan)' (2017) 1 Premise Law Journal.

Nasution, D., Amsia, T. \& M, 'Sistem Pewarisan Pada Masyarakat Batak Toba Di Kecamatan Natar Kabupaten Lampung Selatan' (2015) 3 Jurnal Pendidikan dan Penelitian Sejarah.

Ni Kadek Setyawati, 'Kedudukan Perempuan Hindu Menurut Hukum Waris Adat Bali Dalam Perspektif Kesetaraan Gender' (2017) 1 Jurnal Penelitian Agama Hindu.

Ni Nyoman Sukerti et. al., 'Pewarisan Pada Masyarakat Adat Bali Terkait Ahli Waris Yang Beralih Agama' (2016) 2 Acta Comitas.

Warren J. Blumenfeld, Margaret Soenser Breen, 'Introduction to the Special Issue: Butler Matters: Judith Butler's Impact on Feminist and Queer Studies Since Gender Trouble' (2001) 6 International Journal of Sexuality and Gender Studies.

William Byne et al, 'Gender Dysphoria in Adults: An Overview and Primer for Psychiatrists' (2018) 3 Transgender Health.

\section{Websites}

Hendri F. Isnaeni, 'Viva Vivian' (Historia, 2019) <https://historia.id/kultur/ articles/viva-vivian-6a8JP> accessed 6 April 2020.

\section{Regulations}

Indische Staatsregeling.

How to cite: Katherine Abidea Salim, 'The Status of Transgender Men Heir in Patrilineal System of Adat Inheritance Law' (2020) Vol. 3 No. 1 Media Iuris. 